\title{
In Vivo Antiplasmodial Activities and Acute Toxicity Assessment of Two Plant Cocktail Extracts Commonly Used Among Southwestern Nigerians.
}

Rachel Omagha ( $\nabla$ asking4rachel@yahoo.com )

University of Lagos, Nigeria https://orcid.org/0000-0002-9491-4457

E.T. Idowu

University of Lagos Faculty of Science

C.G. Alimba

University of Ibadan

A.O Otubanjo

University of Lagos Faculty of Science

E.O. Agbaje

University of Lagos College of Medicine

\section{Research Article}

Keywords: Antimalarial efficacy, medicinal plants, cocktail remedies, acute toxicity

Posted Date: April 3rd, 2021

DOl: https://doi.org/10.21203/rs.3.rs-366502/v1

License: (9) This work is licensed under a Creative Commons Attribution 4.0 International License.

Read Full License 
Research Article

IN VIVO ANTIPLASMODIAL ACTIVITIES AND ACUTE TOXICITY ASSESSMENT OF TWO PLANT COCKTAIL EXTRACTS COMMONLY USED AMONG SOUTHWESTERN NIGERIANS.

\author{
Omagha, R. ${ }^{1}$, Idowu, E.T. ${ }^{1}$, Alimba, C.G. ${ }^{2}$, Otubanjo, A.O. ${ }^{1}$, Agbaje E.O. ${ }^{3}$ \\ ${ }^{1}$ Department of Zoology, Faculty of Science, University of Lagos, Lagos Nigeria. \\ ${ }^{2}$ Department of Zoology, Faculty of Science, University of Ibadan, Ibadan Nigeria \\ ${ }^{3}$ Department of Pharmacology, Therapeutics and Toxicology, Faculty of Basic Medical Sciences, University of \\ Lagos, Lagos Nigeria. \\ *Corresponding author: Omagha Rachel. \\ Phone No: 234-8063846124 \\ E-mail: asking4rachel@yahoo.com
}

\begin{abstract}
Discovering and developing the desired antimalarials continue to be a necessity especially due to treatment failures, drug resistance, limited availability and affordability of pharmaceutical antimalarials, costs and logistical problems especially in poor malarious countries. This study investigated the efficacies of two plant cocktails; $\mathrm{CtA}$ and $\mathrm{CtB}$, selected based on their traditional usage. Activities of the cocktail extracts, chloroquine and pyrimethamine against Plasmodium berghei berghei were evaluated using the suppressive, curative and prophylactic test models, after oral and intraperitoneal acute toxicity determination of the plant cocktails in accordance with Lorke method. Data was analyzed using SPSS software version 23.0 with level of significance set at $\mathrm{P}<0.05$. The median lethal dose was determined to be higher than $5000 \mathrm{mg} / \mathrm{kg}$ body weight orally for both $\mathrm{CtA}$ and $\mathrm{CtB}$; and $316.23 \mathrm{mg} / \mathrm{kg}$ body weight intraperitoneally for CtA. Each cocktail exhibited high dose dependent Plasmodium berghei berghei inhibition which was $96.95 \%, 99.13 \%$ in the CtA800 mg/kg, CtB800 mg/kg doses in the curative groups respectively, 96.46\%, 78.62\% for $\mathrm{CtA} 800 \mathrm{mg} / \mathrm{kg}, \mathrm{CtB} 800 \mathrm{mg} / \mathrm{kg}$ doses in the suppressive groups respectively, and $65.05 \%, 88.80 \%$ for $\mathrm{CtA} 800 \mathrm{mg} / \mathrm{kg}, \mathrm{CtB} 800 \mathrm{mg} / \mathrm{kg}$ doses in the prophylactic groups respectively. Throughout the observation periods, the standard drugs, chloroquine phosphate and pyrimethamine maintained higher inhibitions up to $100 \%$. These findings demonstrate that $\mathrm{CtA}$ and $\mathrm{CtB}$ possess good antimalarial abilities and calls for their development and standardization as effective and readily available antimalarial options. The acute toxicity results obtained underscore the importance of obtaining information on toxicities of medicinal plant remedies before their administration in both humans and animals.
\end{abstract}

Key Words: Antimalarial efficacy, medicinal plants, cocktail remedies, acute toxicity

\title{
1.0 INTRODUCTION
}

Malaria remains a major health problem and continues to impact enormously on man's health and economy (WHOWMR 2016). Effective malaria control and eradication depend largely on high-quality case management, vector control and surveillance (WHO 2006; 2012; 2014). Treatment with efficacious antimalarial drugs is crucial at all stages including the early control or "attack" phase to driving down transmission and the later stages of maintaining interruption of transmission, preventing reintroduction of malaria, and eliminating the last residual foci of infection (Bhatt et al., 2015; WHO 2007; 2014; 2016). Substantial work is under way on new medicines to counter the resistance of vectors, to safely target hypnozoites (radical cure), to clear gametocytes and to prevent reinfection (Wells et al., 2015; Burrows et al., 2013; 2017).

Plants may well prove to be the source of new antimalarial drugs in view of the success with the two important chemotherapeutic agents, quinine and artemisinin (the mainstay of malaria treatment), both of which are derived from plants (Ojurongbe et al., 2015). However, the use of Quinine and Artemisinin as antimalarials has been limited by incidences of Plasmodium strains developing resistance against them (WHO-WMR 2011; Ménard et al., 2013; Ashley et al., 2014). Medicinal plants traditionally used to treat malaria therefore continues to be increasingly investigated for ideal antimalarial drugs discovery and development.

There is a growing consensus that drug combinations are essential to the optimal control of malaria, since they offer improved efficacy through synergistic activities (Fidock et al., 2004). Artemisinin-based Combination Therapies (ACTs) - particularly combinations of artemisinin or its semi-synthetic derivatives and a long-lasting drug - are recommended by WHO for treating P. falciparum infections (WHO 2001; 2015; Faurant, 2011; Dawaki et al., 2016). Consequently, drug combination therapy, including the use of polyherbal products, has become the popular method of managing malaria morbidity (Arrey et al., 2014). In recent times, several concoctions of two or more whole plant species or their parts that work in synergy are prepared and administered orally (Adjanohoun et al., 1996; Adebayo 
and Krettli 2011; Ajayi et al., 2017). Despite the increasing level of dependence on this method of management, only a few pharmacological investigations have been carried out on the ever-increasing number of indigeneous polyherbal preparations used to treat malaria fever (Table 1) (Nwabuisi 2002; Ofori-Attah et al., 2012; Martey et al., 2013; Arrey et al., 2014; Idowu et al., 2015.; Adepiti et al., 2016; Okpe et al., 2016; Ibukunoluwa 2017; Orabueze et al., 2018; Omagha et al., 2020). Also, toxicity assessment of these polyherbal preparations are rarely investigated, making it difficult to be generally accepted as safe to public health.

Enantia chlorantha (African yellow wood), Cymbopogon citratus (Lemon grass), Carica papaya (Pawpaw), Mangifera indica (mango), Curcuma longa (Tumeric), Alstonia boonei (Pattern wood) are some of the predominantly used antimalarial medicinal plants in most endemic countries including Nigeria. Despite their popular application in combination antimalarial ethnomedicine, there is no scientific evidence to justify the acclaimed antimalarial efficacy when combined. Therefore, the present study evaluated in vivo antimalarial efficacy and acute toxicity of two plant cocktail extracts in mice following ethno botanical survey of traditional medicine practicioners (manuscript A). The scientific justification of the plant cocktails being investigated may be a springboard for new phytotherapies that could be affordable to treat malaria in Nigeria and in other parts of Sub-Saharan Africa, the most malaria endemic areas in the world.

Table 1: Previous studies validating plant cocktails in malaria treatment

\begin{tabular}{|c|c|c|c|}
\hline Plant species & $\begin{array}{l}\text { Antiplasmodial } \\
\text { activities }\end{array}$ & Safety studies & References \\
\hline $\begin{array}{l}\text { Cajanus cajan + Euphorbia lateriflora + } \\
\text { Mangifera indica + Cassa alata }+ \\
\text { Cymbopogon giganteus }+ \text { Nauclea latifolia }+ \\
\text { and Uvaria chamae }\end{array}$ & $\begin{array}{l}\text { Significant } \\
\text { antiplasmodial activity }\end{array}$ & $\begin{array}{l}\text { No significant side } \\
\text { effects }\end{array}$ & Nwabuisi 2002. \\
\hline A. indica $+C$. papaya $+M$. indica & $\begin{array}{l}\text { Significant } \\
\text { antiplasmodial activity }\end{array}$ & Not done & $\begin{array}{l}\text { Ofori-Attah et al. } \\
2012\end{array}$ \\
\hline $\begin{array}{l}\text { Azadirachta indica }+ \text { Nauclea latifolia }+ \\
\text { Morinda lucida }\end{array}$ & $\begin{array}{l}\text { Significant } \\
\text { antiplasmodial activity }\end{array}$ & No adverse effects. & $\begin{array}{l}\text { Martey et al., } \\
2013\end{array}$ \\
\hline $\begin{array}{l}\text { Nauclea latifolia }+ \text { Artocarpus altilis }+ \\
\text { Murraya koenigii }+ \text { Enantia chlorantha }\end{array}$ & $\begin{array}{l}\text { Significant } \\
\text { antiplasmodial activity }\end{array}$ & Not done & $\begin{array}{l}\text { Adebajo et al., } \\
2014\end{array}$ \\
\hline $\begin{array}{l}\text { Mangifera indica }+ \text { Psidium guajava }+ \text { Carica } \\
\text { papaya }+ \text { Cymbopogon citratus }+ \text { Citrus } \\
\text { sinensis }+ \text { Ocimum gratissimum }\end{array}$ & $\begin{array}{l}\text { Significant } \\
\text { antiplasmodial activity }\end{array}$ & $\begin{array}{l}\text { No adverse acute } \\
\text { toxicity }\end{array}$ & Arrey et al., 2014 \\
\hline Ficus exasperata + Anthocleista vogelii & $\begin{array}{l}\text { Significant } \\
\text { antiplasmodial activity }\end{array}$ & $\begin{array}{l}\text { Increased size of } \\
\text { liver, spleen }\end{array}$ & $\begin{array}{l}\text { Okpok et al., } \\
2014\end{array}$ \\
\hline P. nitida + A. boonei + G. Latifolia . & $\begin{array}{l}\text { Significant } \\
\text { antiplasmodial activity }\end{array}$ & $\begin{array}{l}\text { Elevated ALT,AST } \\
\text { and creatinine. }\end{array}$ & $\begin{array}{l}\text { Idowu et al., } \\
2015 .\end{array}$ \\
\hline $\begin{array}{l}\text { Mangifera indica }+ \text { Alstonia boonei }+ \\
\text { Morinda lucida }+ \text { Azadirachta indica }\end{array}$ & $\begin{array}{l}\text { Significant } \\
\text { antiplasmodial activity }\end{array}$ & Not done & $\begin{array}{l}\text { Adepiti et al., } \\
\text { 2014; } 2016\end{array}$ \\
\hline Vernonia amygdalina + Carica papaya & $\begin{array}{l}\text { Significant } \\
\text { antiplasmodial activity }\end{array}$ & $\begin{array}{l}\text { Increased RBC and } \\
\text { PCV. Histology } \\
\text { indicated hepatic } \\
\text { cell damage }\end{array}$ & Okpe et al., 2016 \\
\hline $\begin{array}{l}\text { Anthocleista djalonensis A. Chev. + } \\
\text { Azadirachta indica A. Juss + Cajanus } \\
\text { cajan (L.) Huth. + Crescentia cujete L. + } \\
\text { Lawsonia inermis L. + Lophira alata Banks ex } \\
\text { C.F. Gaertn. + Myrianthus pruessii Engl. + } \\
\text { Nauclea latifolia Sm. + Olax subscorpioidea } \\
\text { Oliv. + Terminalia glaucescens }\end{array}$ & $\begin{array}{l}\text { Significant } \\
\text { antiplasmodial activity }\end{array}$ & $\begin{array}{l}\text { Histological } \\
\text { studies revealed } \\
\text { some pathology. }\end{array}$ & $\begin{array}{l}\text { Ibukunoluwa } \\
2017\end{array}$ \\
\hline $\begin{array}{l}\text { Fadogia cienkowskii }+ \text { Lophira lanceolata }+ \\
\text { Vernonia conferta }+ \text { Protea madiensis }\end{array}$ & $\begin{array}{l}\text { Significant } \\
\text { antiplasmodial activity }\end{array}$ & No adverse effects & $\begin{array}{l}\text { Orabueze et al., } \\
2018\end{array}$ \\
\hline
\end{tabular}

2.0 MATERIALS AND METHODS

2.1 Preparation of plant cocktail extracts and reference drugs: Based on information collected from herbal practitioners in south west Nigeria (manuscript A), powdered hot water extracts of A. boonei (stem bark), C. papaya 
(fruits), C. citratus (leaves), C. longa (roots), $M$. indica (stem bark) and E. chlorantha (Stem bark) were combined in ratios to prepare two popularly used polyherbal remedies from indigenous plants. Cocktail treatment $\mathrm{A}(\mathrm{CtA}): 4: 2: 1$ (E. chlorantha:C citratus:C. longa). Cocktail treatment B (CtB): 4:2:1:1 (E. chlorantha:A. boonei:C. papaya:M. indica). The two cocktail treatments were obtained by separately dissolving $10 \mathrm{~g}$ of each components $(\mathrm{CtA}=5.70 \mathrm{~g}+$ $2.87 \mathrm{~g}+1.43 \mathrm{~g}$; and $\mathrm{CtB}=5.00 \mathrm{~g}+2.33 \mathrm{~g}+1.27 \mathrm{~g}+1.27 \mathrm{~g}$ ) in $200 \mathrm{ml}$ distilled water equivalent to $50 \mathrm{mg} / \mathrm{ml} \mathrm{concentration}$. The resulting combinations were separately heated over a water bath for 30minutes and left to cool, labelled and refrigerated at $4^{\circ} \mathrm{C}$ in air-tight bottles. Doses administered for CtA and CtB, $(200 \mathrm{mg} / \mathrm{kg}, 400 \mathrm{mg} / \mathrm{kg}$ and $800 \mathrm{mg} / \mathrm{kg})$ were appropriately chosen for antimalarial evaluation based on acute toxicity results established by this study. Chloroquine phosphate (CQ) and Pyrimethamine (PY) manufactured in Ikeja, Lagos Nigeria by Vitabiotics Limited, and SKG-Pharma Limited respectively are the standard drugs used as positive controls. The doses required for each of the standard drugs, $25 \mathrm{mg} / \mathrm{kg}$ and $5 \mathrm{mg} / \mathrm{kg}$ respectively (Iwalokun 2008; Alli et al., 2011) were given according to weight of each animal. They were each prepared by diluting: $250 \mathrm{mg}$ tablet strength of CQ in $25 \mathrm{mls}$ of distilled water $(10 \mathrm{mg} / \mathrm{ml})$, and $25 \mathrm{mg}$ tablet strength of PY in $5 \mathrm{mls}$ of distilled water $(5 \mathrm{mg} / \mathrm{ml})$. A measure of $10 \mathrm{ml} / \mathrm{kg} \mathrm{distilled} \mathrm{water}$ (DW) was given as negative control.

Table 2: Concentrations for treatments administered.

\section{Treatments}

\begin{tabular}{|c|c|c|c|c|}
\hline \multirow[t]{2}{*}{ Standard drugs } & Chloroquine (CQ) & $\mathrm{CQ} 25 \mathrm{mg} / \mathrm{kg}$ & & \\
\hline & Pyrimethamine (PY) & PY5 mg/kg & & \\
\hline \multirow[t]{2}{*}{ Cocktail extracts } & Cocktail treatment A (CtA) & $\mathrm{CtA} 200 \mathrm{mg} / \mathrm{kg}$ & $\mathrm{CtA} 400 \mathrm{mg} / \mathrm{kg}$ & $\mathrm{CtA} 800 \mathrm{mg} / \mathrm{kg}$ \\
\hline & Cocktail treatment $\mathrm{B}(\mathrm{CtB})$ & $\mathrm{CtB} 200 \mathrm{mg} / \mathrm{kg}$ & $\mathrm{CtB} 400 \mathrm{mg} / \mathrm{kg}$ & $\mathrm{CtB} 800 \mathrm{mg} / \mathrm{kg}$ \\
\hline \multicolumn{2}{|c|}{ Distilled water (DW) } & DW10 mg/kg & & \\
\hline
\end{tabular}

2.2 Plasmodium parasite species and animals: Chloroquine-sensitive Plasmodium berghei berghei parasites was obtained from Institute for Advanced Medical Research and Training, (IMRAT), University of Ibadan, Ibadan, Nigeria, by intraperitoneal inoculation of uninfected mice with $0.2 \mathrm{ml}$ of the diluted blood from previously infected mice maintained by successive intra-peritoneal inoculation of parasite-free mice every four days. The donor mice were then transported to the University of Lagos animal house where they were kept under standard laboratory conditions with constant access to food and water until the desired level of parasitemia was achieved. Infected blood from the donor mouse was obtained by cardiac puncture. Infected red cells/ $\mu 1$ was calculated using the relative value method, count of infected red cells X 5000000/total red cells counted (infected + non-infected). This was done to determine the required standard inoculum of $1 \times 10^{6}$ using thin blood films of donor mice. Five millilitres normal saline, a quantity determined by the level of parasitaemia of the infected donor mice was used to dilute $2 \mathrm{ml}$ of the donor blood.

A total of 120 adult male mice of about 7 - 8 weeks old, weighing between $16-20 \mathrm{~g}$ were obtained from the Animal House, University of Lagos, where the animal exposures during this study was conducted. Before being subjected to experiment they were left for two weeks to acclimatize to laboratory conditions, and had constant access to feed on a standard rodent's diet consisting of crude protein, fat, calcium, available phosphate, vitamins, crude fiber and tap water. They were kept in plastic cages with metal covers for free passage of air, and at room temperature of about $27^{\circ} \mathrm{C}$.

2.3 Acute toxicity (LD $\left.D_{50}\right)$ test of the plant cocktails: A lethal dose for fifty percent of the mice $\left(\mathrm{LD}_{50}\right)$ test was performed on the two cocktail treatments, CtA and CtB in accordance with (Lorke 1983) method. This test was done to observe the mice for signs of toxicity including clogging together, weakness, anorexia, micturition, respiratory distress, coma, and mortality for the first $24 \mathrm{~h}$ and thereafter daily for 14 days. The tests were replicated in two groups, group 1 treated orally and group 2 treated intraperitoneally. A total of 48 mice was used for this test. In the phase 1 of the method, 9 animals divided into three groups of 3 animals was orally administered different doses $(10 \mathrm{mg} / \mathrm{kg}, 100$ $\mathrm{mg} / \mathrm{kg}$ and $1000 \mathrm{mg} / \mathrm{kg}$ ) of the test substances CtA and CtB, and observed for 24 hours. Another 9 animals divided into three groups of 3 animals each was intraperitoneally administered different doses $(10 \mathrm{mg} / \mathrm{kg}, 100 \mathrm{mg} / \mathrm{kg}$ and 1000 $\mathrm{mg} / \mathrm{kg}$ ) of the test substances CtA and $\mathrm{CtB}$, and observed for 24 hours. In the phase 2 of the method, further specific doses were administered to calculate an $\mathrm{LD}_{50} .3$ animals divided into three groups of 1 animal each were orally administered different doses $(1600 \mathrm{mg} / \mathrm{kg}, 2900 \mathrm{mg} / \mathrm{kg}$ and $5000 \mathrm{mg} / \mathrm{kg}$ ) of CtA. This was replicated for CtB. Another 3 animals divided into three groups of 1 animal each were intraperitoneally administered different doses $(1600 \mathrm{mg} / \mathrm{kg}$, $2900 \mathrm{mg} / \mathrm{kg}$ and $5000 \mathrm{mg} / \mathrm{kg}$ ) of CtA. This was replicated for CtB. The $\mathrm{LD}_{50}$ was calculated as the square root of the product of the lowest lethal dose and highest non-lethal dose, i.e., the geometric mean of the consecutive doses for 
which 0 and $100 \%$ survival rates were recorded in the second phase, using the formula: $\mathrm{LD}_{50}=\sqrt{ }(\mathrm{D} 0 \mathrm{X} \mathrm{D} 100)$; $\mathrm{D} 0=$ highest dose that gave no mortality, D100 = lowest dose that produced $100 \%$ mortality.

2.4 Antimalarial activities of CtA and CtB: The antimalarial efficacy of the cocktail extracts CtA and CtB in rodent malaria parasites was evaluated using the suppressive, curative and prophylactic test models. The body weight of each mouse for all the tests was taken before and after exposure. $0.2 \mathrm{ml}$ of the prepared P. berghei berghei parasitized erythrocytes suspension in normal saline was injected intraperitoneally into each mouse to be used for the tests using one (1) ml syringe and needle. The drugs and plant cocktails were orally administered with the aid of oral cannula. Thick and thin smears fixed in $100 \%$ methanol stained with $10 \%$ Giemsa's stain at $\mathrm{pH} 7.2$ for 15 min were prepared from the tail blood of each mouse. Prepared blood films were air dried at room temperature and examined microscopically under oil immersion (X100 magnification). The parasitaemia was determined by counting the number of parasitized erythrocytes in 2000 cells in random fields of the microscope. The percentage parasitaemia was determined using the formular: Number of parasitized RBCs/Total number of RBCs (infected + Non-infected) x 100\% (Fidock et al., 2004). The mean parasite count for each group were determined and the percentage chemo inhibition for each dose was calculated as [(A-B)/A], where A is the average percentage of parasitaemia in the negative control and $\mathrm{B}$ is the average percentage of parasitaemia in the test groups (Kalra et al., 2006).

2.4.1 Rane Curative Test: was conducted according to Ryley and Peters (1970) in a similar method adopted by Iwalokun (2008); Alli et al., (2011). Seventy-two hours after infection with chloroquine sensitive P. berghei, 40 infected mice were divided into 8 groups of 5 animals each. 3 groups were orally administered different doses $(200 \mathrm{mg} / \mathrm{kg}, 400 \mathrm{mg} / \mathrm{kg}$ and $800 \mathrm{mg} / \mathrm{kg}$ respectively) of CtA. The same treatment was replicated for CtB using another 3 groups of the animals. The $7^{\text {th }}$ group was administered chloroquine phosphate $(25 \mathrm{mg} / \mathrm{kg})$ as positive control, while the $8^{\text {th }}$ group received $10 \mathrm{mg} / \mathrm{kg}$ distilled water as negative control. Each mouse was treated orally once daily with the dose given according to body weight of animal for 5 consecutive days (D4-D8) post inoculation during which the parasitaemia level were monitored daily.

2.4.2 The 4-day Suppressive Test: Peters (1965) 4-day suppressive test in mice was conducted in a similar method reported by Mesia et al., (2005); Iwalokun (2008); Alli et al., (2011). 40 mice divided into 8 groups of 5 animals each were inoculated intraperitoneally on the first day (Do) with Plasmodium berghei berghei parasitized red blood cells. The mice were then treated immediately after day 0 to day 3. 3 groups were orally administered different doses $(200 \mathrm{mg} / \mathrm{kg}, 400 \mathrm{mg} / \mathrm{kg}$ and $800 \mathrm{mg} / \mathrm{kg}$ respectively) of CtA according to body weight of animal. The same treatment was replicated for $\mathrm{CtB}$ using another 3 groups of the animals. The $7^{\text {th }}$ group was administered chloroquine phosphate $\left(25 \mathrm{mg} / \mathrm{kg}\right.$ ) as positive control, while the $8^{\text {th }}$ group received $10 \mathrm{mg} / \mathrm{kg}$ distilled water as negative control. All treatments were given according to body weight of animal. Parasitaemia levels were monitored daily from day 4 to day 7 .

2.4.3 Repository (Prophylactic) Test: Adopted the method of Peters (1965) and as similarly followed in Alli et al., (2011). A total of 40 mice were divided into 8 groups of 5 animals. 3 groups were orally administered different doses $(200 \mathrm{mg} / \mathrm{kg}, 400 \mathrm{mg} / \mathrm{kg}$ and $800 \mathrm{mg} / \mathrm{kg}$ respectively) of CtA. The same treatment was replicated for $\mathrm{CtB}$ using another 3 groups of the animals. The seventh group was given $5 \mathrm{mg} / \mathrm{kg}$ of pyrimethamine, while the last group (negative control) received $10 \mathrm{mg} / \mathrm{kg}$ distilled water for four consecutive days. On the fourth day (D4), the mice were inoculated with P. berghei berghei. Seventy two hours later (D7), smears were made from the mice (D7-D11) to assess parasitaemia levels.

\subsection{Ethical considerations}

The Ethics Committee at the Nigerian Institute of Medical Research Institutional Review Board (NIMR IRB) reviewed and granted approval (assigned number IRB/17/036) for this study.

2.6 Data analysis: Data from anti-plasmodial curative, suppressive and prophylactic assays were entered and analyzed using Microsoft Excel version 2016 and Statistical Package for Social Sciences (SPSS) version 23.0. The differences between means among negative and positive controls as well as treatment groups were compared for significance using one way analysis of variance (ANOVA), followed by Dunnett's multiple post hoc test. Differences were considered significant to negative control when Probability value $(\mathrm{P}<0.05)$. Results obtained were presented using bar charts.

\subsection{RESULTS}

3.1 Acute toxicity of CtA and CtB in mice: Acute oral toxicity assessment of both CtA and CtB showed dosedependent reduced activity and clogging together within the first six hours at the phase 2 treatments. All the mice survived both phases within the $24 \mathrm{~h}$ and 2 -weeks observation periods. The oral median lethal dose of both CtA and $\mathrm{CtB}$ was calculated to be greater than $5000 \mathrm{mg} / \mathrm{kg}$ in mice (Table 3a). In the intraperitioneal acute toxicity assessment, there were remarkable dose-dependent reduced activity and clogging together in the phase 1 treatments with 1000 
$\mathrm{mg} / \mathrm{kg}$ dose of both cocktails, and at all doses in phase 2 with CtB. Within $24 \mathrm{~h}, 100 \%$ mortality was recorded for CtB and $33 \%$ for CtA, though mortality for CtA reached $100 \%$ within 7 days observation period. Within $24 \mathrm{~h}, 100 \%$ mortality was recorded for CtA at all doses in phase 2. No further exposure was done for the group receiving CtA following a $100 \%$ mortality observed at $1000 \mathrm{mg} / \mathrm{kg}$ in phase 1 . Acute intraperitioneal toxicity assessment was calculated to be $316.23 \mathrm{mg} / \mathrm{kg}$ in mice for CtA. (Table $3 \mathrm{~b}$ ).

Table 3a: Acute toxicity $\left(\mathrm{LD}_{50}\right)$ results from oral administration

\begin{tabular}{|c|c|c|c|c|c|c|c|c|c|c|}
\hline Cocktails & $\begin{array}{l}\text { Route of } \\
\text { Administration }\end{array}$ & $\begin{array}{l}\text { No } \\
\text { of } \\
\text { mice }\end{array}$ & $\begin{array}{l}\text { Dose } \\
(\mathrm{mg} / \mathrm{kg})\end{array}$ & $\begin{array}{l}\text { Weakness/Redu } \\
\text { ced activity }\end{array}$ & $\begin{array}{l}\text { Clogging } \\
\text { Together }\end{array}$ & $\begin{array}{l}\text { Day } 0 \\
\text { Mortality }\end{array}$ & $\begin{array}{l}\% \\
\text { Mortality }\end{array}$ & $\begin{array}{l}\mathrm{LD}_{50} \\
(\mathrm{mg} / \mathrm{kg})\end{array}$ & $\begin{array}{l}\text { Day } 7 \\
\text { Mortality }\end{array}$ & $\begin{array}{l}\text { Day } 14 \\
\text { Mortality }\end{array}$ \\
\hline \multicolumn{11}{|c|}{ LORKE'S PHASE 1} \\
\hline \multirow[t]{3}{*}{ CtA } & Orally & 3 & 10 & No & No & 0 & 0 & & 0 & 0 \\
\hline & & 3 & 100 & No & No & 0 & 0 & & 0 & 0 \\
\hline & & 3 & 1000 & No & No & 0 & 0 & & 0 & 0 \\
\hline \multirow[t]{3}{*}{ CtB } & Orally & 3 & 10 & No & No & 0 & 0 & & 0 & 0 \\
\hline & & 3 & 100 & No & No & 0 & 0 & & 0 & 0 \\
\hline & & 3 & 1000 & No & No & 0 & 0 & & 0 & 0 \\
\hline \multicolumn{11}{|c|}{ LORKE'S PHASE 2} \\
\hline \multirow[t]{3}{*}{ CtA } & Orally & 1 & 1600 & Yes & Yes & 0 & 0 & $\mathrm{CtA}>\mathbf{5 0 0 0}$ & 0 & 0 \\
\hline & & 1 & 2900 & Yes & Yes & 0 & 0 & & 0 & 0 \\
\hline & & 1 & 5000 & Yes & Yes & 0 & 0 & $\mathrm{CtB}>5000$ & 0 & 0 \\
\hline \multirow[t]{3}{*}{ CtB } & Orally & 1 & 1600 & No & Yes & 0 & 0 & & 0 & 0 \\
\hline & & 1 & 2900 & Yes & Yes & 0 & 0 & & 0 & 0 \\
\hline & & 1 & 5000 & Yes & Yes & 0 & 0 & & 0 & 0 \\
\hline
\end{tabular}

Table 3b: Acute toxicity $\left(\mathrm{LD}_{50}\right)$ results from intraperitioneal administration

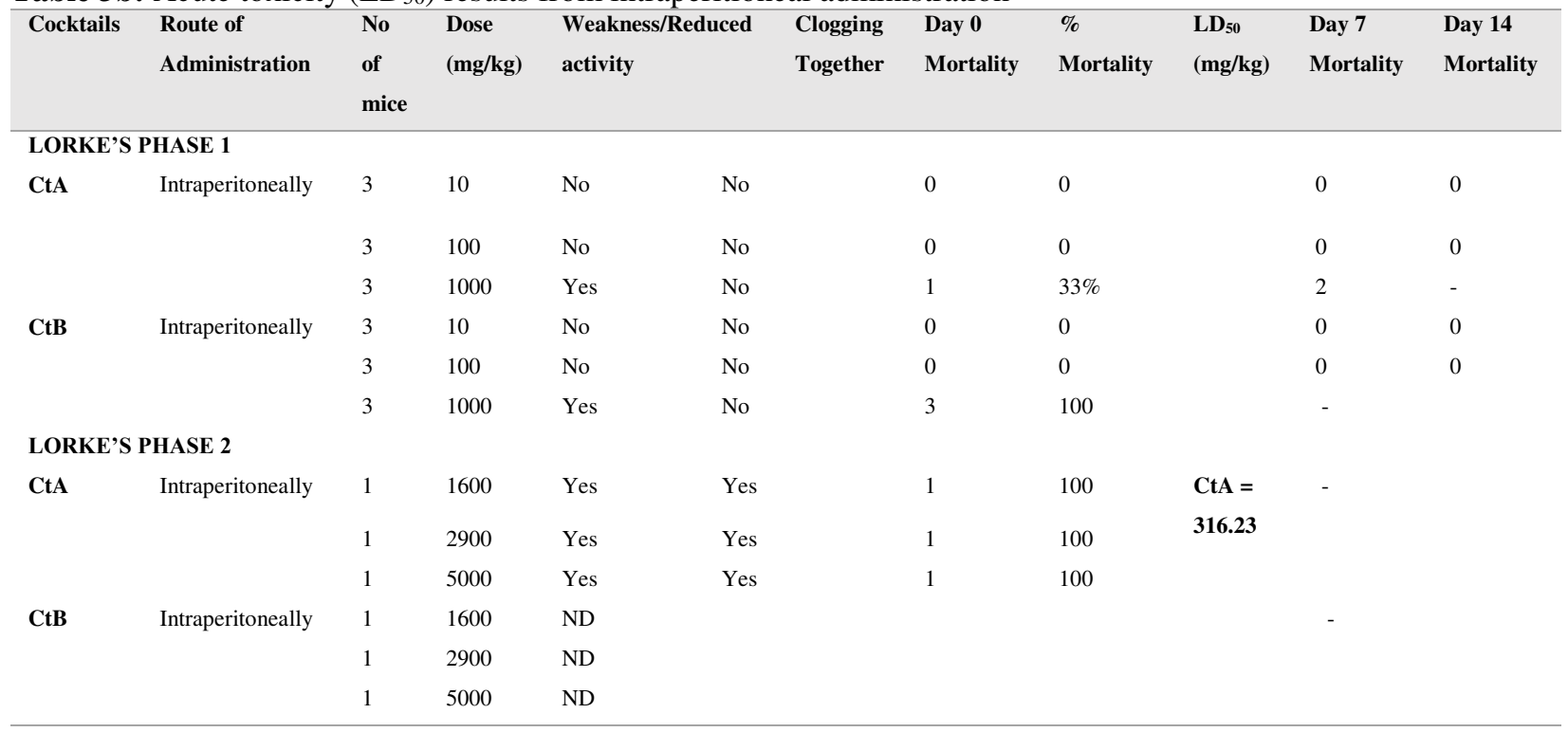

\subsection{In vivo antimalarial efficacies of $\mathrm{CtA}$ and $\mathrm{CtB}$}

Curative ability on established infection: Curative effects in all the treated groups increased from day 4 to day 8 . Parasite inhibition was $100 \%$ with CQ25 $\mathrm{mg} / \mathrm{kg}$ from day 2 till day 5 of observation. In the extract treated groups, inhibition was observed to be $88.50 \%, 94.77 \%$ and $96.95 \%$ in the CtA200 mg/kg, CtA400 mg/kg and CtA800 mg/kg doses respectively; and $74.82 \%, 91.81 \%$ and $99.13 \%$ in the $\mathrm{CtB} 200 \mathrm{mg} / \mathrm{kg}, \mathrm{CtB} 400 \mathrm{mg} / \mathrm{kg}$ and $\mathrm{CtB} 800 \mathrm{mg} / \mathrm{kg}$ doses respectively.

Suppressive ability on early infection: Throughout the four days of observation, parasitaemia was $100 \%$ inhibited in the CQ25 mg/kg group. In the groups treated with the plant cocktails, inhibition increased at all doses, and by day 6 , reached $63.82 \%, 89.54 \%$ and $96.46 \%$ at the $\mathrm{CtA} 200 \mathrm{mg} / \mathrm{kg}, \mathrm{CtA} 400 \mathrm{mg} / \mathrm{kg}$ and CtA800mg/kg doses respectively; and $33.84 \%, 51.92 \%$ and $78.62 \%$ for $\mathrm{CtB} 200 \mathrm{mg} / \mathrm{kg}, \mathrm{CtB} 400 \mathrm{mg} / \mathrm{kg}$ and CtB800mg/kg doses respectively. 
Prophylactic ability on residual infection: Result shows inhibition with PY $5 \mathrm{mg} / \mathrm{kg}$ to be $100 \%$ throughout the 5 days of observation. With the cocktail extract-treated groups, at the beginning of observation (D7), parasite inhibition was $42.34 \%, 50.88 \%$ and $65.05 \%$ for the CtA200 mg/kg, CtA $400 \mathrm{mg} / \mathrm{kg}$ and CtA800mg/kg doses respectively; and $65.05 \%, 60.57 \%$ and $88.80 \%$ for $\mathrm{CtB} 200 \mathrm{mg} / \mathrm{kg}, \mathrm{CtB} 400 \mathrm{mg} / \mathrm{kg}$ and CtB800mg/kg doses respectively. However, a decreased parasite inhibition was observed as the observation proceeded, and by D11, parasite inhibition was $26.12 \%$, $55.14 \%$ and $57.09 \%$ for the $\mathrm{CtA} 200 \mathrm{mg} / \mathrm{kg}, \mathrm{CtA} 400 \mathrm{mg} / \mathrm{kg}$ and $\mathrm{CtA} 800 \mathrm{mg} / \mathrm{kg}$ doses respectively; and $8.53 \%, 25.59 \%$ and $47.42 \%$ for the CtB200 mg/kg, CtB400 mg/kg and CtB800mg/kg doses respectively.

Figures 1 (a-c) below shows the percentage inhibition of $P$. berghei berghei in mice.

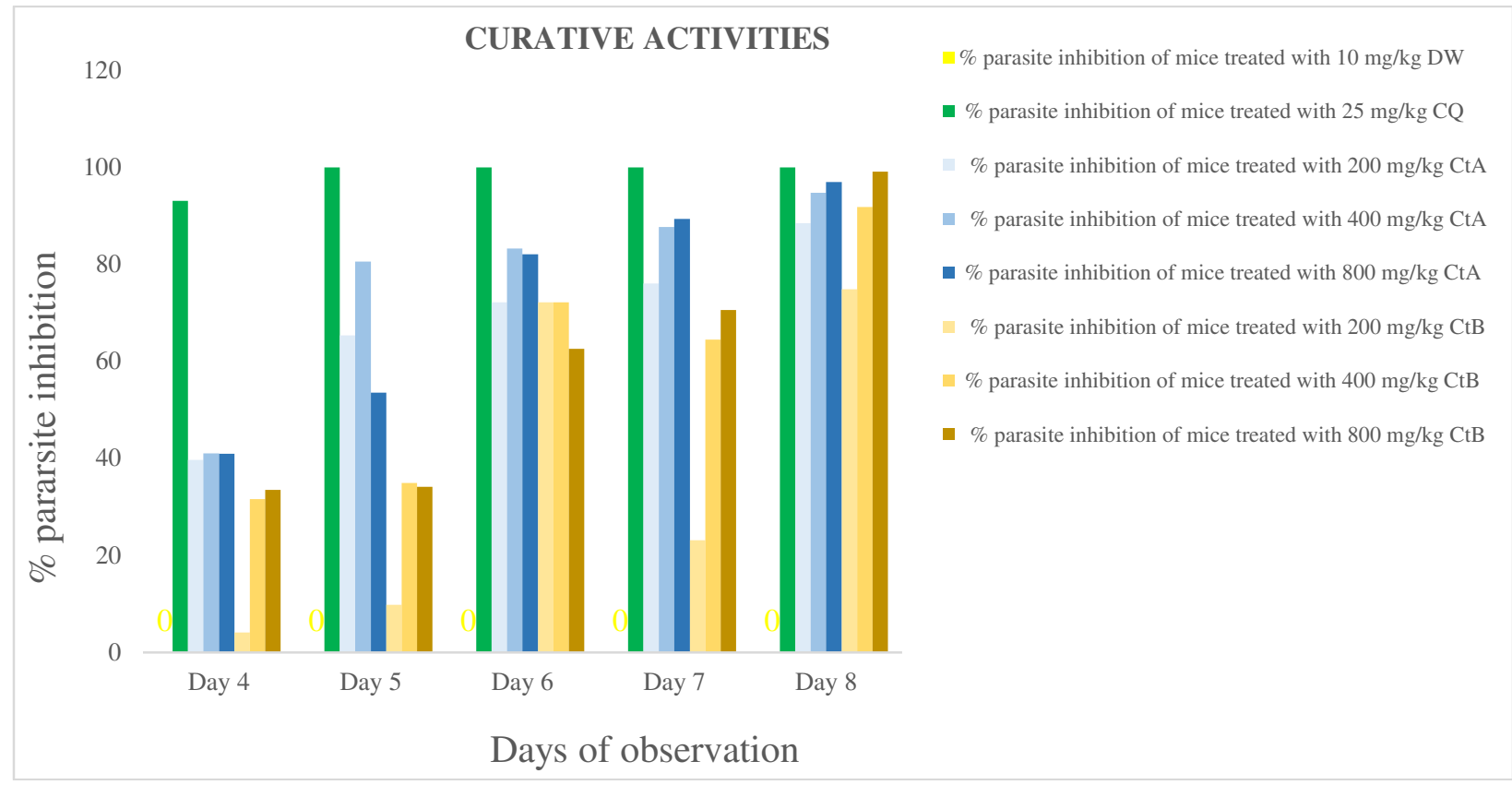

Figure 1a: Curative ability of treatments on established infection

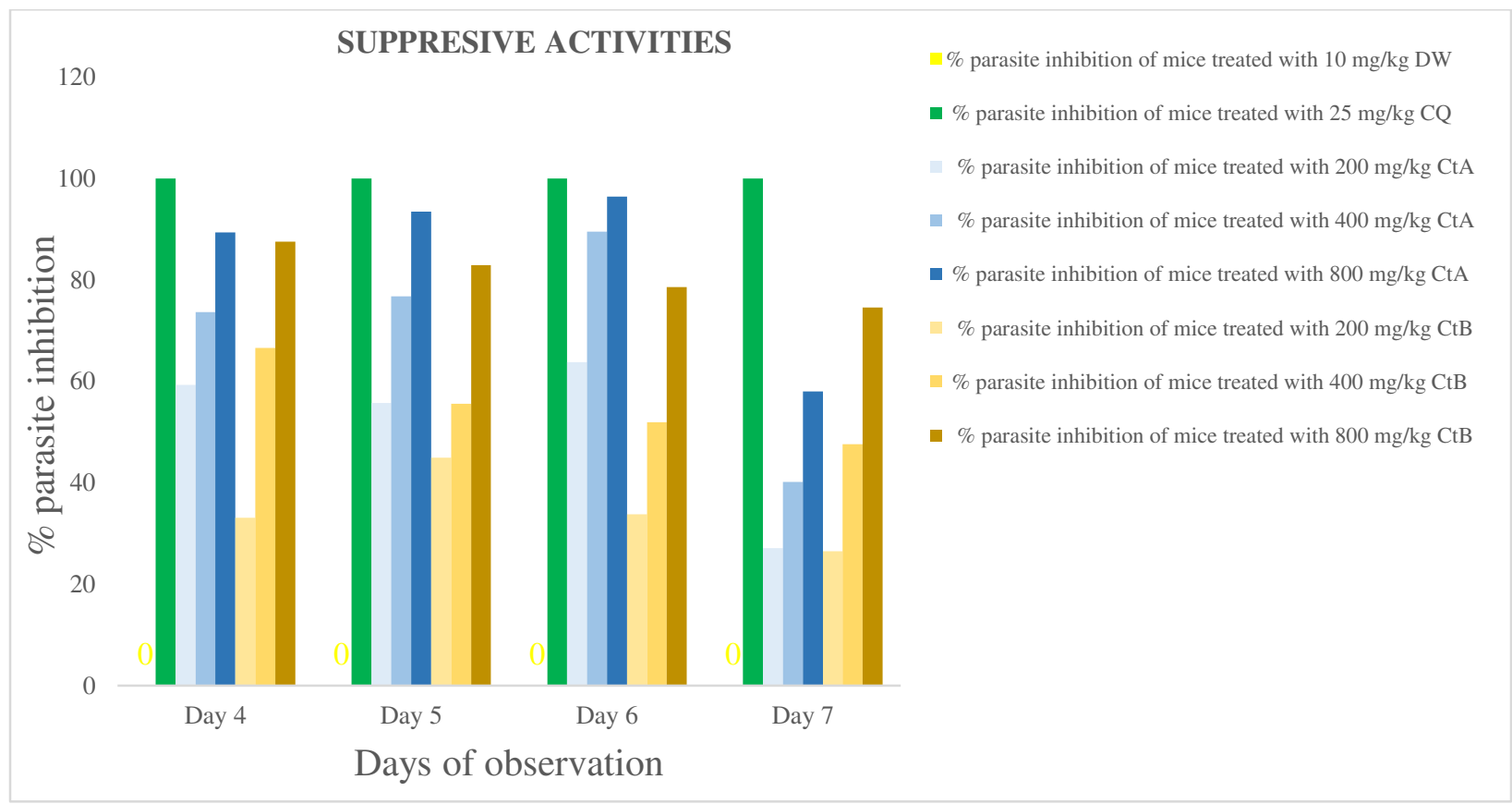

Figure 1b: Suppressive ability of treatments on early malaria infection 


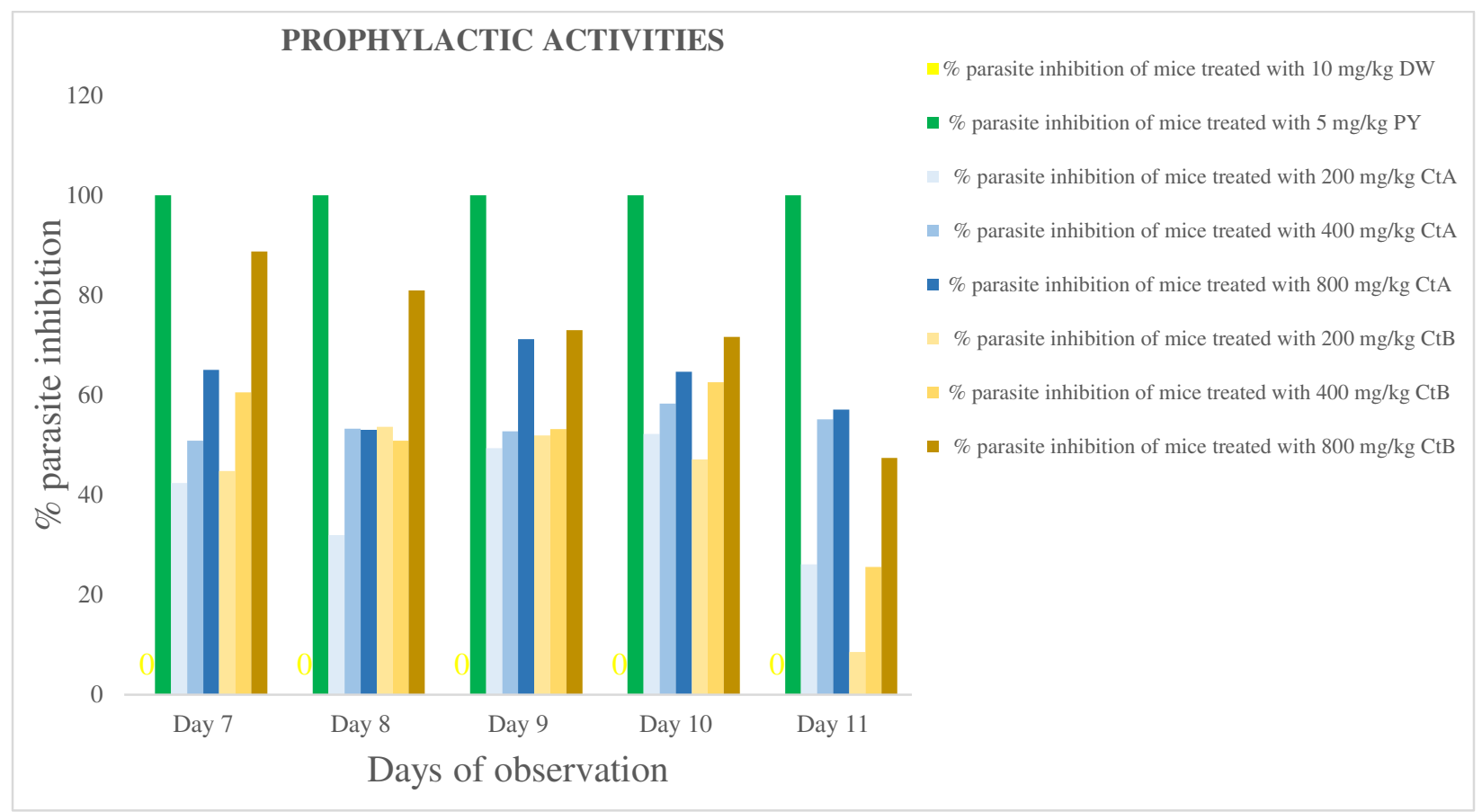

Figure 1c: Prophylactic ability of treatments on residual infection

\subsection{DISCUSSION}

Acute toxicity was evaluated to observe for toxicity signs and mortality associated with administration of CtA and $\mathrm{CtB}$ in mice. The oral and intraperitoneal routes' toxicity effects in this study varied with dosage concentrations. Lethal oral dose of $\mathrm{CtA}$ and $\mathrm{CtB}$ was evaluated to be less toxic than the intraperitoneal administration, emphasizing a need to establish any toxicity before choosing the routes of administration. This findings suggests the safe use of the plants by the locals who reported oral route as the most popular mode of administration of these cocktail recipes in malaria treatment (manuscript A). The toxic effects reported of these cocktail recipes in mice is expected to serve as baseline for further studies, for comparison in mammalian anatomy and physiology (Ibukunoluwa 2017; Jutamaad $e t$ al., 1998) and encourage advocacies for their regulated oral use as complementary therapies. The results of acute toxicity generally serve in choosing appropriate test doses of $\mathrm{CtA}$ and $\mathrm{CtB}$ for antimalarial evaluation in investigation.

Earlier studies have reported the traditional antimalarial uses and the monotherapeutic activities of $C$. papaya, $C$. longa, A. boonei, M. indica, E. chlorantha and C. citratus (Agbaje and Onabanjo 1991; Awe et al., 1998; Bhat and Surolia 2001; Udeh et al., 2001; Aiyeloja and Bello 2006; Idowu et al., 2010). This study reports the antiplasmodial activity of two polyherbal recipes from the above mentioned plants: CtA comprising E. chlorantha + C. citratus $+C$. longa, and $\mathrm{CtB}$ comprising E. chlorantha $+A$. boonei $+C$. papaya $+M$. indica. Similar investigation on the antiplasmodial activities of some other polyherbal recipes in malaria treatments have reported noteworthy efficacies (Nwabuisi 2002; Ofori-Attah et al., 2012; Martey et al., 2013; Adebajo et al., 2014; Arrey et al., 2014; Idowu et al., 2015; Adepiti et al., 2016; Okpe et al., 2016, Ibukunoluwa 2017; Orabueze et al., 2018).

In all three models (curative, suppressive and prophylactic), results showed that $\mathrm{CtA}$ and $\mathrm{CtB}$ significantly inhibited parasitaemia, with inhibition levels up to $90 \%$ in the 400 and $800 \mathrm{mg} / \mathrm{kg}$ doses of each cocktail extracts in the curative and suppressive models. The findings confirms antiplasmodial potency of $\mathrm{CtA}$ and $\mathrm{CtB}$, provides scientific basis for their usage as antimalarial remedies and proves they are potential sources that should be explored for new antimalarial drugs. Chloroquine, an antimalarial drug still widely used in Nigeria because it is accessible and affordable, and despite WHO recommendation for Artemisinin Combination Therapies ACTs, (WHO 2001; Oladipo et al., 2015) was used as the reference drug in curative and suppressive models (Iwalokun 2008; Alli et al., 2011), and Pyrimethamine was the standard antimalarial drug used in the prophylactic model (Alli et al., 2011). These standard drugs inhibited parasitaemia to undetectable levels and the findings agrees with results from other studies validating medicinal plants in malaria treatments (Alli et al., 2011; Ogbole et al., 2014). The total clearance of parasitaemia by chloroquine compares very closely to the $99.13 \%$ curative ability demonstrated in this study at the $800 \mathrm{mg} / \mathrm{kg}$ of CtB. 
Phytochemical analysis plays a vital role in the observation of the efficacies of the plant materials in therapeutic preparations. The antiplasmodial activity observed in these plant cocktails could be attributed to the presence of some of the antimalarial proven phytochemicals including saponin, alkaloid, flavonoid, phenol and lactones (Kirby et al., 1989; Philipson and Wright 1991; Christensen and Kharazmi 2001; Onifade and Maganda 2015; Ibukunoluwa 2017; Omagha et al., 2020) present in each of the plants used in the combinations for CtA and CtB. These phytoconstituents affect the condition and function of body organs, clear up residual symptoms of the disease. They help increase the body's resistance to disease or facilitate the adaptation of the organism to certain conditions (Forantisek 2001). However, the potential toxicity of plant products is understudied. A few scientific evidences available from toxicological studies have reported some phytochemicals to be potentially toxic thus affecting their safe use (Bode and Dong 2015; Mensah et al., 2019).

Multidrug strategy in therapeutic applications is expected to increase efficacy of two or more anti-infective agents (Bennet et al., 2015), improve clinical cure, shorten the duration of therapy so as to minimize the risk of recrudescence, and provide a way in which resistance can be delayed (WHO 2001). Our results showed that the action of the combination therapies in this study significantly differed from the plant materials acting individually in previous studies (Agbaje and Onabanjo 1991; Longdet and Adoga 2017; Awe et al., 1998; Onifade and Maganda 2015). The improved efficacy demonstrated by these findings and extent of use by locals who rely on them to combat high burdens of malaria morbidity and mortality calls for further studies to understand activities and actual behaviours of these combined plant materials in malaria treatments.

\section{Conclusions}

Malaria control continues to rely upon antimalarial plant remedies increasingly used as combination therapies. Findings in this study demonstrates that plant-based cocktail treatments CtA and CtB possess good antimalarial abilities and safer in oral administrations compared to intraperitioneal administrations. Following the efficacies established in this study, further investigations concerning their safety is currently ongoing to determine the potential toxicity-related adverse reactions while using $\mathrm{CtA}$ and $\mathrm{CtB}$ in malaria treatment.

\section{Acknowledgment}

The authors are grateful to Prof. O. G. Ademowo of the Institute of Advanced Medical Research and Training (IMRAT), University College Hospital, Ibadan, Nigeria, for kindly supplying the rodent parasite, Plasmodium berghei berghei NK 65. Dr. Akeem Kadiri, Department of Botany and Microbiology, University of Lagos, Lagos Nigeria is also appreciated for assistance identifying the 6 plant materials collected from medicinal plants growers at Oje, Ibadan. Mr. Samuel Akindele and Mr Olakiigbe A.K. of the Department of Biochemistry, Nigerian Institute of Medical Research (NIMR), Yaba, Lagos is also acknowledged for technical assistance.

\section{REFERENCES}

Adebayo, J. O., and Krettli, A. U. (2011). Potential antimalarials from Nigerian plants: a review. Journal of ethnopharmacology, 133(2), 289-302.

Adepiti, A. O., Elujoba, A. A., and Bolaji, O. O. (2016). Evaluation of herbal antimalarial MAMA decoctionamodiaquine combination in murine malaria model. Pharmaceutical biology, 54(10), 2298-2303.

Adjanohoun, J. E., Aboubakar, N., Dramane, K. et al. (1996). Contribution to Ethnobotanical and Floristic Studies in Cameroon, Scientific, Technical and Research Commission, Organization of African Unity, Addis Ababa, Ethiopia.

Agbaje, E. O., and Onabanjo, A. O. (1991). The effects of extracts of Enantia chlorantha in malaria. Annals of Tropical Medicine \& Parasitology, 85(6), 585-590.

Aiyeloja, A. A., and Bello, O. A. (2006). Ethnobotanical potentials of common herbs in Nigeria: A case study of Enugu state. Educational Research and Reviews, 1(1), 16-22.

Ajayi, E. I. O., Adeleke, M. A., Adewumi, T. Y., and Adeyemi, A. A. (2017). Antiplasmodial activities of ethanol extracts of Euphorbia hirta whole plant and Vernonia amygdalina leaves in Plasmodium berghei-infected mice. Journal of Taibah University for Science, 11(6), 831-835.

Alli, L. A., Adesokan, A. A., Salawu, O. A., Akanji, M. A., and Tijani, A. Y. (2011). Anti-plasmodial activity of aqueous root extract of Acacia nilotica. African Journal of Biochemistry Research, 5(7), 214-219.

Arrey Tarkang, P., Franzoi, K. D., Lee, S., Lee, E., Vivarelli, D., Freitas-Junior, L., and Okalebo, F. A. (2014). In vitro antiplasmodial activities and synergistic combinations of differential solvent extracts of the polyherbal product, Nefang. BioMed research international, 2014. 
Awe, S. O., Olajide, O. A., Oladiran, O. O., and Makinde, J. M. (1998). Antiplasmodial and antipyretic screening of Mangifera indica extract. Phytotherapy Research: An International Journal Devoted to Pharmacological and Toxicological Evaluation of Natural Product Derivatives, 12(6), 437-438.

Ashley, E. A., Dhorda, M., Fairhurst, R. M., Amaratunga, C., Lim, P., Suon, S., and Sopha, C. (2014). Spread of artemisinin resistance in Plasmodium falciparum malaria. New England Journal of Medicine, 371(5), 411423.

Bennet, J. E., Blaser, M. J., and Dolin, R. (2015). Principles and practice of infectious diseases. Elsevier Saunders.

Bhat, G. P., and Surolia, N. (2001). In vitro antimalarial activity of extracts of three plants used in the traditional medicine of India. The American journal of tropical medicine and hygiene, 65(4), 304-308.

Bhatt, S., Weiss, D. J., Cameron, E., Bisanzio, D., Mappin, B., Dalrymple, U., and Wenger, E. A. (2015). The effect of malaria control on Plasmodium falciparum in Africa between 2000 and 2015. Nature, 526(7572), 207.

Bode, A. M., and Dong, Z. (2015). Toxic phytochemicals and their potential risks for human cancer. Cancer prevention research, $8(1), 1-8$.

Burrows, J. N., van Huijsduijnen, R. H., Möhrle, J. J., Oeuvray, C., and Wells, T. N. (2013). Designing the next generation of medicines for malaria control and eradication. Malaria journal, 12(1), 187.

Christensen, S. B., and Kharazmi, A. (2001). Antimalarial natural products. Isolation, characterization and biological properties In: Tringali C, editor. Bioactive compounds from natural sources: isolation, characterization and biological properties.

Dawaki, S., Al-Mekhlafi, H. M., Ithoi, I., Ibrahim, J., Atroosh, W. M., Abdulsalam, A. M., and Ahmed, A. (2016). Is Nigeria winning the battle against malaria? Prevalence, risk factors and KAP assessment among Hausa communities in Kano State. Malaria journal, 15(1), 351.

Ettebong, E., Etuk, E. U., Ubulom, P., Ekpenyong, C., Okokon, J. E., and Udobi, C. E. (2015). Antiplasmodial and antidiarrhoeal activities of Dicliptera verticillata leaf extract. Journal of Phytopharmacology, 4, 73-9.

Faurant, C., (2011). From bark to weed: the history of artemisinin. Parasite;18(3):215-218.

Fidock, D. A., Rosenthal, P. J., Croft, S. L., Brun, R., \& Nwaka, S. (2004). Antimalarial drug discovery: efficacy models for compound screening. Nature reviews Drug discovery, 3(6), 509-520.

Ibukunoluwa, M. R. (2017). In vivo anti-plasmodial activity and histopathological analysis of water and ethanol extracts of a polyherbal antimalarial recipe. Journal of Pharmacognosy and phytotherapy, 9(6), 87-100.

Idowu, E. T., Ajaegbu, H. C., Omotayo, A. I., Aina, O. O., and Otubanjo, O. A. (2015). In vivo anti-plasmodial activities and toxic impacts of lime extract of a combination of Picralima nitida, Alstonia boonei and Gongronema latifolium in mice infected with Chloroquine-sensitive Plasmodium berghei. African health sciences, 15(4), 1262-1270.

Idowu, O. A., Soniran, O. T., Ajana, O., and Aworinde, D. O. (2010). Ethnobotanical survey of antimalarial plants used in Ogun State, Southwest Nigeria. African Journal of Pharmacy and Pharmacology, 4(2), 055-060.

Iwalokun, B. A. (2008). Enhanced antimalarial effects of chloroquine by aqueous Vernonia amygdalina leaf extract in mice infected with chloroquine resistant and sensitive Plasmodium berghei strains. African Health Sciences, 8(1), 25-35.

Jutamaad, N. S., Aimon, S., and Yodhtai, T. (1998). Toxicological and antimalarial activity of the eurycomalactone and Eurycoma longifolia Jack extracts in mice. Thai J Phytopharmacy;5(2):14-27.

Kalra, B. S., Chawla, S., Gupta, P., and Valecha, N. (2006). Screening of antimalarial drugs: An overview. Indian Journal of Pharmacology, 38(1), 5.

Kirby, G. C., O'Neill, M. J., Phillipson, J. D., and Warhurst, D. C. (1989). In vittro studies on the mode of action of quassinoids with activity against chloroquine-resistant Plasmodium falciparum. Biochemical Pharmacology, 38(24), 4367-4374.

Longdet, I. Y., and Adoga, E. A. (2017). Effect of methanolic leaf extract of Carica papaya on Plasmodium berghei infection in albino mice. European Journal of Medicinal Plants, 1-7.

Lorke, D. (1983). A new approach to practical acute toxicity testing. Archives of toxicology, 54(4), 275-287.

Maroyi, A. (2013). Traditional use of medicinal plants in south-central Zimbabwe: review and perspectives. Journal of ethnobiology and ethnomedicine, 9(1), 31 .

Martey, O. N. K., Shittah-Bay, O., Owusu, J., and Okine, L. K. N. (2013). The Antiplasmodial Activity of an Herbal Antimalarial, AM 207 in Plasmodium berghei-infected Balb/c Mice: Absence of Organ Specific Toxicity. Journal of Medical Sciences, 13(7), 537-545.

Ménard, D., et. al., (2013). Global analysis of Plasmodium falciparum $\mathrm{Na}+\mathrm{H}+$ exchanger (pfnhe-1) allele polymorphism and its usefulness as a marker of in vitro resistance to quinine. Int J Parasitol 3, 8-19 (2013).

Mensah, M. L. K., Komlaga, G., Forkuo, A. D., Firempong, C., Anning, A. K., and Dickson, R. A. (2019). Toxicity and safety implications of herbal medicines used in Africa, Herbal Medicine, Philip F. Builders, IntechOpen. 
Nwabuisi, C. (2002). Prophylactic effect of multi-herbal extract 'Agbo-Iba'on Malaria induced in mice. East African medical journal, 79(7), 343-346.

Ofori-Attah, K., Oseni, L. A., Quasie, O., Antwi, S., and Tandoh, M. (2012). A comparative evaluation of in vivo antiplasmodial activity of aqueous leaf exracts of Carica papaya, Azadirachta indica, Magnifera indica and the combination thereof using plasmodium infected balb/c mice.

Ogbole, E. A., Ogbole, Y., Peter, J. Y., Builders, M. I., and Aguiyi, J. C. (2014). Phytochemical screening and in vivo antiplasmodial sensitivity study of locally cultivated artemisia annua leaf extract against Plasmodium berghei. Am J Ethnomed, 1(1), 42-49.

Ojurongbe, O., Ojo, J. A., Adefokun, D. I., Abiodun, O. O., Odewale, G., and Awe, E. O. (2015). In vivo antimalarial activities of Russelia equisetiformis in Plasmodium berghei infected mice. Indian journal of pharmaceutical sciences, 77(4), 504.

Okpe, O., Habila, N., Ikwebe, J., Upev, V. A., Okoduwa, S. I., and Isaac, O. T. (2016). Antimalarial Potential of Carica papaya and Vernonia amygdalina in Mice Infected with Plasmodium berghei. Journal of tropical medicine, 2016.

Oladipo, O.O., Wellington, O.A. and Sutherland, C.J. Persistence of chloroquine-resistant haplotypes of Plasmodium falciparum in children with uncomplicated Malaria in Lagos, Nigeria, four years after change of chloroquine as first-line antimalarial medicine. Diagn Pathol 10, 41 (2015).

Omagha, R., Idowu, E.T., Alimba, C.G., Otubanjo, A. O., Agbaje E.O., and Ajaegbu H.C.N. (2020). Physicochemical and phytochemical screening of six plants commonly used in the treatment of malaria in Nigeria. Journal of Phytomedicine and Therapeutics: Vol 19(2), $520-538$.

manuscript A

Onifade, O. F., and Maganda, V. (2015). In vivo activity of ethanolic extract of Alstonia boonei leaves against Plasmodium berghei in Mice. Journal for Worldwide Holistic Sustainable Development, 1 (4), 60-68.

Orabueze, C. O. I., Sunday, A. A., Duncan, O. A., and Herbert, C. A. (2018). In vivo antiplasmodial activities of four Nigerian plants used singly and in polyherbal combination against Plasmodium berghei infection.

Peters, W. (1965). Drug resistance in Plasmodium bergheiVincke and Lips, 1948. I. Chloroquine resistance. Experimental parasitology, 17(1), 80-89.

Philipson, J. D., and Wright, C. W. (1991). Antiprotozoal compounds from plants sources. Planta medica, 57, 553559.

Ryley, J.F., Peters, W. (1970). The antimalarial activity of some quinone esters. Annals of Tropical Medicine and Parasitology 84, 209-222.

Udeh, M. U., Agbaji, A. S., Williams, I. S., Ehinmidu, P., Ekpa, E., and Dakare, M. (2001). Screening for antimicrobial potentials of Azadirachta indica seed oil and essential oil from Cymbopogoncitratus and Eucalyptus citriodora leaves. Nigerian Journal of Biochemistry and Molecular Biology, 16, 189-92.

Wells, T. N., Van Huijsduijnen, R. H., and Van Voorhis, W. C. (2015). Malaria medicines: a glass half full?. Nature Reviews Drug Discovery, 14(6), 424.

World Health Organization (2014). "Policy Brief on Malaria Diagnostics in Low-Transmission Settings." WHO, Geneva.

World Health Organisation (2001). Antimalarial drug combination therapy: report of a WHO Technical Consultation. World Health Organization, Geneva. WHO/CDS/RBM/2001.35.

World Health Organisation (2011). World malaria report. Geneva, Switzerland.

World Health Organisation (2015). World malaria report. Geneva, Switzerland.

World Health Organisation (2016). World malaria report. Geneva, Switzerland.

World Health Organization (2006). Malaria Vector Control and Personal Protection: Report of a WHO Study Group. WHO Technical Report Series 936. Geneva: WHO.

World Health Organization (2007). Malaria Elimination: A Field Manual for Low and Moderate Endemic Countries. Geneva: WHO.

World Health Organization (2012). "Drug Resistance Threatens Malaria Control.” WHO, Geneva.

World Health Organization (2016). "Eliminating Malaria.” WHO, Geneva.

World Health Organization, (2001). Antimalarial drug combination therapy: report of a WHO technical consultation. Geneva, Switzerland.

World Health Organization, (2003). Assessment and monitoring of antimalarial drug efficacy for the treatment of uncomplicated faciparum malaria. Geneva. 
Figures

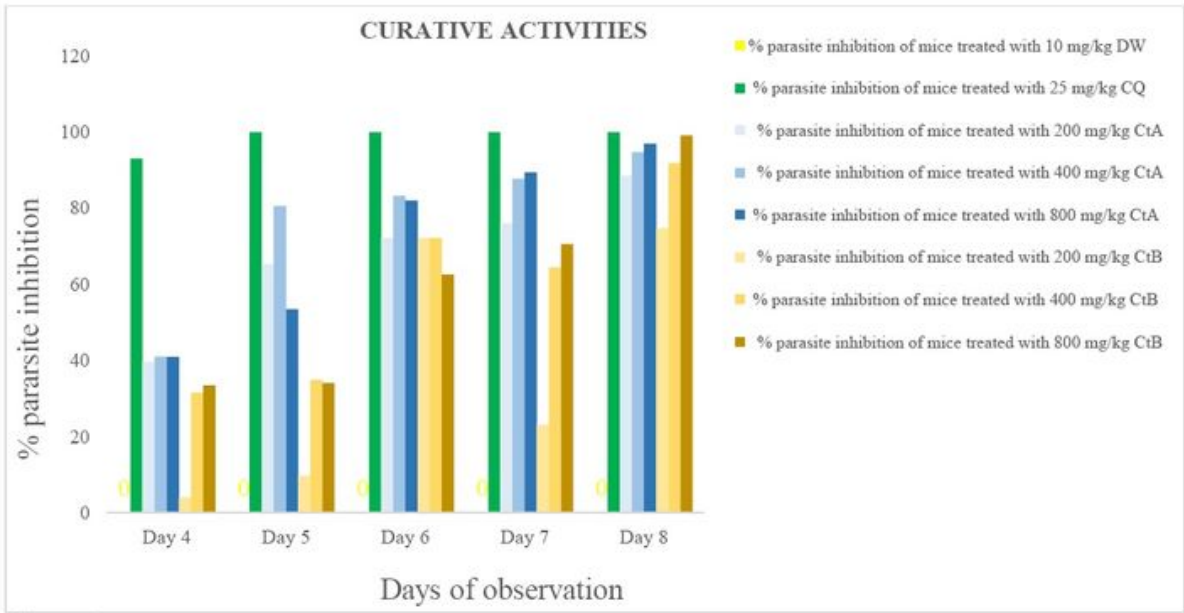

Figure 1a:

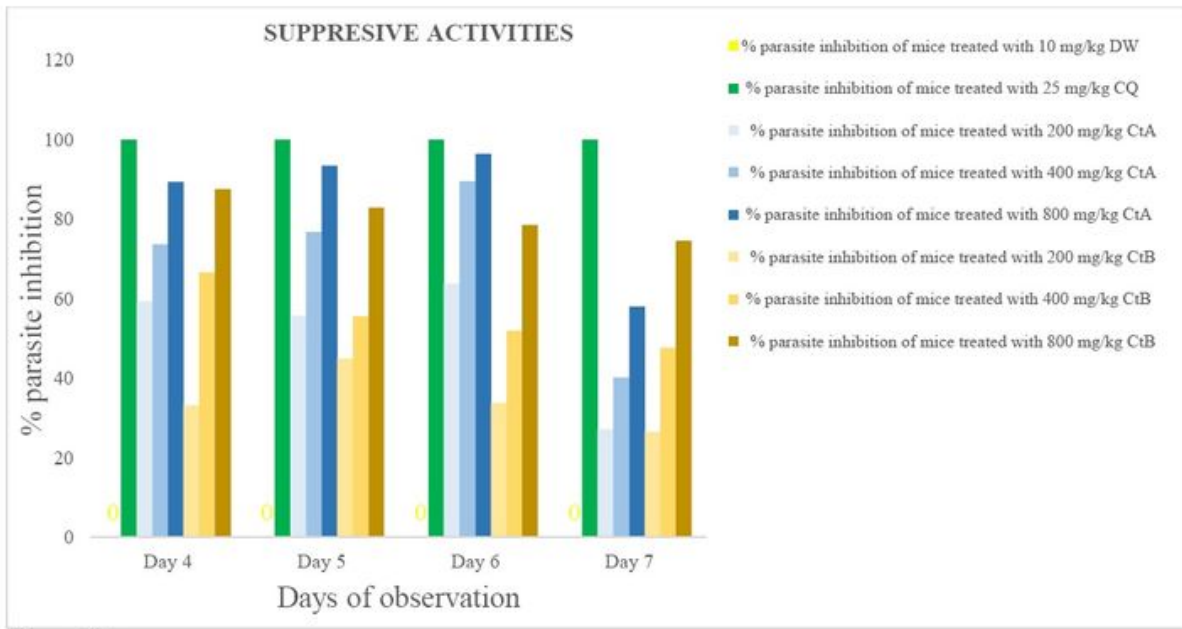

Figure 1b:

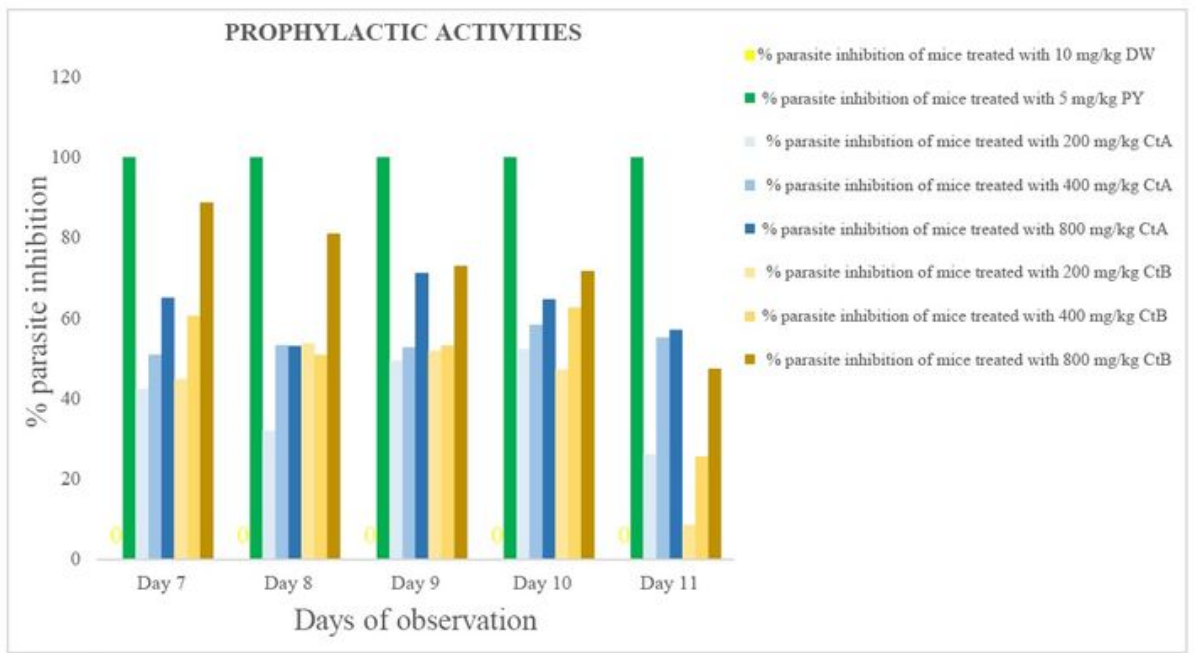

Figure 1c:

\section{Figure 1}

1a: Curative ability of treatments on established infection $1 \mathrm{~b}$ : Suppressive ability of treatments on early malaria infection 1c: Prophylactic ability of treatments on residual infection 